\title{
Abiotic stress caused by foliar applications of boron to the yellow diploid potato (Solanum tuberosum, Group Phureja) cultivar Criolla Galeras
}

\section{Estrés abiótico causado por aplicaciones foliares de boro en papa amarilla diploide (Solanum tuberosum, Grupo Phureja) cultivar Criolla Galeras}

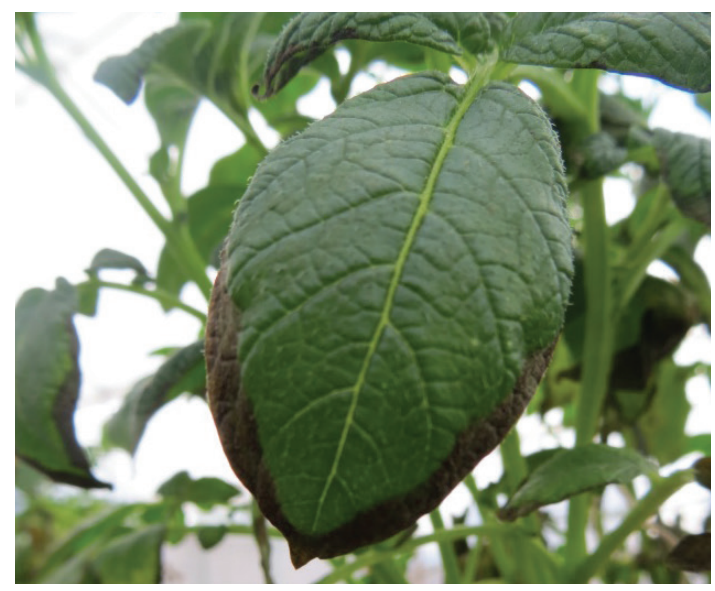

MANUEL IVÁN GÓMEZ1, 3

HERMANN RESTREPO ${ }^{1}$

LUIS ERNESTO RODRÍGUEZ

STANISLAV MAGNITSKIY'

LADY MANRIQUE ${ }^{2}$

ALFONSO GARZÓN²

Toxicity symptoms of boron in the yellow diploid potato cultivar Criolla Galeras.

Photo: M.I. Gómez

\begin{abstract}
Foliar applications of boron (B) constitute a frequent practice in the fertilization of the yellow diploid potato and are generally done with excessive and empirical doses generating toxicities in crops. The effect of foliar applications of $\mathrm{B}$ at doses of $0,0.5,1.2$, or $4 \mathrm{~kg} \mathrm{ha}^{-1}$ was determined for physiological and metabolic variables and toxicity symptoms in the yellow diploid potato cultivar Criolla Galeras under greenhouse conditions using $\mathrm{Na}$ octaborate $(20.5 \% \mathrm{~B}, 11 \% \mathrm{Na})$ or boric acid $(17.5 \% \mathrm{~B})$ as sources of B. Significant differences $(P<0.05)$ were found between the sources and doses for dry matter (DW), leaf area (LA), proline content, and electrolyte leakage (ECh). The highest toxicity was observed for B applied as sodium octaborate at concentrations of 2 and $4 \mathrm{~kg} \mathrm{ha}^{-1} \mathrm{~B}$ with a reduction of DM up to $40 \%$, a decrease of LA up to $90 \%$, a loss of $60 \%$ in $\mathrm{ECh}$, and a significant increase in the concentration of proline $(65 \mu \mathrm{mol} / \mathrm{g}$ fresh weight). The lower toxicity of boric acid at doses higher than $2 \mathrm{~kg} \mathrm{ha}^{-1} \mathrm{~B}$ indicated that the octaborate $\mathrm{Na}$ presented synergism with $\mathrm{B}$, which can result in a greater oxidative stress, causing instability of the membranes, necrosis and premature tissue death, as evidenced in the description of the visual symptoms. The doses of 0.5 and $1.0 \mathrm{~kg} \mathrm{ha}^{-1} \mathrm{~B}$ for both sources resulted in positive responses in the DW and non-significant $(P<0.05)$ differences with the control, associated with the levels of proline and $\mathrm{ECh}$, which indicated a narrow range between the deficiency and

\footnotetext{
Universidad Nacional de Colombia, Facultad Ciencias Agrarias, Departamento de Agronomía, Bogota (Colombia). ORCD Gómez, M.I.: 0000-0002-1469-7676; ORCID Restrepo, H.: 0000-0002-1838-5872; ORCID Rodríguez, L.E.: 0000-0002-9058-8404; ORCID Magnitskiy, S.: 0000-0002-3715-1932 Agronómica, Bogota (Colombia). ORCID Manrique, L.: 0000-0001-8927-235X; ORCID Garzón, A.: 0000-0001-76020620
}

2 Universidad Nacional de Colombia, Facultad Ciencias Agrarias, Departamento de Agronomía, Programa de Ingeniería

3 Corresponding author. igomezm@unal.edu.co
\end{abstract}


toxicity of B for $\mathrm{cv}$. Criolla Galeras, where the effect of the accompanying ion must be considered in the selection of the boron source.

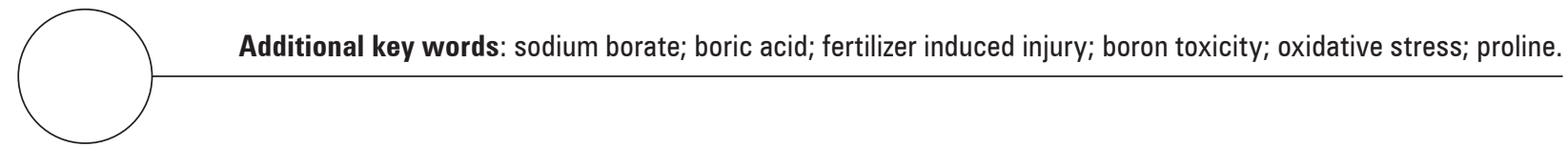

\section{RESUMEN}

La aplicación foliar de boro (B) es una práctica frecuente en el manejo de la fertilización en papa amarilla diploide, generalmente, se realiza de manera excesiva y empírica generando toxicidades en el cultivo. Se determinó bajo condiciones de invernadero el efecto de la aplicación foliar de $\mathrm{B}$ en dosis de $0 ; 0,5 ; 1,2$ y $4,0 \mathrm{~kg} \mathrm{ha}^{-1}$, utilizando como fuentes octaborato de $\mathrm{Na}(20,5 \% \mathrm{~B}, 11 \% \mathrm{Na})$ o ácido bórico $(17,5 \%$ B), sobre variables fisiológicas, metabólicas y síntomas de toxicidad en papa amarilla diploide cultivar Criolla Galeras. Se presentaron diferencias significativas $(P<0,05)$ entre fuentes y dosis para materia seca (MS), área foliar (AF), contenido de prolina y pérdida de electrolitos (CEh). Se observó una mayor toxicidad por B cuando se aplicó octaborato de sodio en concentraciones de 2 y $4 \mathrm{~kg} \mathrm{ha}^{-1} \mathrm{~B}$ con un detrimento para MS hasta del $40 \%$, disminución del AF hasta del $90 \%$, pérdida del $60 \%$ de CEh e incremento significativo en la concentración de prolina ( $65 \mu \mathrm{mol} / \mathrm{g}$ de peso fresco). La mayor toxicidad de ácido bórico a dosis mayores a $2 \mathrm{~kg} \mathrm{ha}^{-1} \mathrm{~B}$ indicó que el Na proveniente de la fuente de octaborato creó un sinergismo con el B, lo cual puede incidir en un mayor estrés oxidativo, causando inestabilidad de membranas, necrosis y muerte prematura en tejidos como se evidenció en la descripción de la sintomatología visual. Las dosis de 0,5 y 1,0 $\mathrm{kg}_{\text {ha }}{ }^{-1} \mathrm{~B}$ para ambas fuentes resultaron en respuestas positivas en MS y no significativas $(P<0,05)$ con el control, asociado a niveles de prolina y CEh, que comprueban el rango estrecho entre deficiencia y toxicidad para el cv. Criolla Galeras, donde se debe considerar el efecto del ion acompañante en la selección de la fuente.

Palabras clave adicionales: borato de sodio; ácido bórico; daños por fertilizantes; toxicidad por boro; estrés oxidativo; prolina.

Received for publication: 29-06-18 Accepted for publication: 30-11-2018

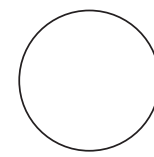

INTRODUCTION

Yellow diploid potato o potato criolla (Solanum tuberosum L. Group Phureja) corresponds to the diploid morphotypes, with tubers with a yellow skin and flesh color (egg yolk phenotype) (Rodríguez et al., 2009). Colombia is the main commercial producer, largest consumer and exporter of diploid potatoes in the world, with the competitive advantages of being the center of diversity and wide acceptance among consumers because of its organoleptic characteristics, which makes the potato criolla one of the genetic resources of high importance in the country (Herrera and Rodríguez, 2011). For 2016, approximately 10,683 ha of this crop were planted, for an annual production of 170,000 t. The Cundinamarca, Nariño, and Boyaca provinces have the highest production (Agronet, 2016).
Boron phytotoxicity is observed with the presence of chlorosis and necrosis in the tips and margins of the leaves, with subsequent intermittent burning; it starts in mature leaves, and chlorosis and necrotic margins could be evidenced under severe toxicity conditions in the leaves of the medium strata (Herrera et al., 2010; Metwally et al., 2012). This reflects the poor mobility of B through phloem in Solanaceae species (Di Gioia et al., 2017), which could be influenced by the transpiration rate and other factors (Brown and $\mathrm{Hu}, 1998$; Eichert and Goldbach, 2010).

Plants absorb $\mathrm{B}$ in the form of anion borate $\mathrm{B}(\mathrm{OH})^{4-}$ or boric acid $\mathrm{B}(\mathrm{OH})_{3}$ (Brown and $\left.\mathrm{Hu}, 1998\right)$. One of the primary functions of $B$ in plants is related to the structure of cell walls (Herrera et al., 2010; Metwally 
et al., 2012), where B integrates rhamnogalacturonan II of pectin and promotes growth, cell wall rigidity, and membrane stability (Archana and Verma, 2017). However, an excess of $\mathrm{B}$ could produce membrane alterations and oxidative damage through lipid peroxidation with excessive accumulation of hydrogen peroxide (Herrera et al., 2010; Reid, 2010). B toxicity in tomatoes results in increased activity of antioxidant enzymes derived from the ascorbate cycle (Cervilla et al., 2012); in addition, B toxicity causes an increase in levels of malondialdehyde in potatoes (Ayvaz et al., 2013) and a release of electrolytes in radish cells (Siddiqui et al., 2013). These parameters are used as indicators of B toxicity affecting cell membranes (Mohammed et al., 2002; Barrett and Douglass, 2004; Siddiqui et al., 2013).

Another stress response as a result of B toxicity in plants has been observed with the biosynthesis of non-enzymatic antioxidants, such as glutathione and cysteine, in sunflowers (Ruiz et al., 2003) and with different pathways of proline synthesis in rice, depending on the intensity of the B stress (Dominic and Jithin, 2012); the accumulation of proline in Solanaceae has been also observed, such as in tomatoes (Solanum lycopersicum) (Cervilla et al., 2012). Proline accumulates in the cytosol and allows an osmotic adjustment, which stabilizes subcellular structures, regulates redox potential, and blocks free radical production under excess B (Bonilla and González, 2011; Cervilla et al., 2012).

In Colombia, B is applied with foliar spraying on yellow diploid potatoes with variable doses, without knowledge on toxicity or physiological and metabolic responses for tetraborate sodium and boric acid although it is presumed from field experiences that a B source accompanied by $\mathrm{Na}$ could be more toxic than boric acid, which is related to absorption and mobility conditions as well as toxic effects potentiated by the presence of $\mathrm{Na}$ (Dominic and Jithin, 2012). On the other hand, foliar B applications have been shown to be an effective alternative in mineral nutrition with this element, where periodic applications should be made during the growth phase to avoid B toxicity resulting from possible accumulation of $B$ in plants because of its low mobility (Fernández et al., 2013).

The management of foliar $\mathrm{B}$ applications under conditions of $B$ deficiency or low availability favors production with $B$ doses that can vary between 400 to $1000 \mathrm{~g} \mathrm{ha}^{-1}$ per cycle depending on the species (Castro and Gómez, 2010; Fernández et al., 2013).
The objective of this study was to determine the effects of different boron supply treatments and the effects of foliar application of B with sources of high solubility (sodium borate and boric acid) on changes in growth and physiological parameters in yellow diploid cv. Criolla Galeras.

\section{MATERIALS AND METHODS}

\section{Plant material and location}

The experimental phase was carried out in the first semester of 2013 in the greenhouses of the Faculty of Agricultural Sciences, of the Universidad Nacional de Colombia, Bogota characterized by an average PAR of $393.07 \mu \mathrm{mol} \mathrm{m}^{-2} \mathrm{~s}^{-1}$, average air temperature of $26.3^{\circ} \mathrm{C}$, and average air humidity of $58.5 \%$. Tubers of yellow diploid potato cv. Criolla Galeras of a homogeneous size $(3-4 \mathrm{~cm})$ were planted individually in plastic bags with $1.5 \mathrm{~kg}$ of soil. After 30 days of planting (DAP), a balanced edaphic maintenance fertilization was carried out according to the soil chemical analysis. The soil was classified as Typic Hapludand with average contents of $\mathrm{B}(<0.6 \mathrm{mg}$ $\mathrm{kg}^{-1}$, extraction by monobasic phosphate). The measurements of the plant response to the B applications were done 90 DAP.

\section{Experimental design and treatments}

Four foliar applications of B were carried out during the study, distributing the total dose during growth (Tab. 1). Each spraying was done with surfactant adjuvant (1 $\mathrm{ml} \mathrm{L}^{-1}$ Transfer $^{\circledR}$ Adhex) at an interval of $4 \mathrm{~d}$, starting at $45 \mathrm{DAP}$ using $13 \mathrm{ml}$ of water per plant per application, which corresponded to 400 $\mathrm{L} \mathrm{ha} \mathrm{a}^{-1}$ (average application volume in the field). A completely randomized design was used with nine treatments (Tab. 1) and four replicates; each replicate corresponded to one plant. An analysis of variance was performed, and Tukey's mean comparison test $(P \leq 0.05)$ between the treatments was applied using Infostat ${ }^{\circledR}$ (National University of Cordoba, Argentina). Additionally, Sperman correlation analysis was used. To determine the response of the interaction between the sources and doses, a $2 \times 4$ factorial analysis was carried out for each of the variables, where the main factor was the B sources (boric acid, sodium borate), and the secondary factor was the $\mathrm{B}$ doses $\left(0.5,1.0,2.0\right.$, or $4.0 \mathrm{~kg} \mathrm{ha}^{-1}$ per cycle). 
Table 1. Treatments and doses of boron applied via foliar on yellow diploid potato cv. Criolla Galeras.

\begin{tabular}{|c|c|c|c|c|c|c|c|}
\hline \multirow{2}{*}{$\begin{array}{l}\text { No. } \\
\text { treatment }\end{array}$} & \multirow{2}{*}{ Sources } & \multicolumn{3}{|c|}{ Foliar dose of elemental B } & \multicolumn{3}{|c|}{ Foliar dose of source B } \\
\hline & & $\mathrm{kg} \mathrm{ha}^{-1^{*}}$ & $\mathrm{mM}$ & $\mathrm{g} \mathrm{L}^{-1}$ ** & $\mathrm{kg} \mathrm{ha}^{-1 * * *}$ & $\mathrm{~g} \mathrm{~L}^{-1^{*}}$ & $\mathrm{~g} \mathrm{~L}^{-1 * *}$ \\
\hline 1 & \multirow{4}{*}{ Boric acid (17.5\% B) } & 0.5 & 28.6 & 0.31 & 2.86 & 7.14 & 1.79 \\
\hline 2 & & 1.0 & 58.2 & 0.63 & 5.71 & 14.29 & 3.57 \\
\hline 3 & & 2.0 & 115.6 & 1.25 & 11.43 & 28.57 & 7.14 \\
\hline 4 & & 4.0 & 231.2 & 2.50 & 22.86 & 57.14 & 14.29 \\
\hline 5 & \multirow{4}{*}{$\begin{array}{l}\text { Sodium borate }(20.5 \% \\
\text { B) }\end{array}$} & 0.5 & 28.6 & 0.31 & 2.44 & 6.10 & 1.52 \\
\hline 6 & & 1.0 & 58.2 & 0.63 & 4.88 & 12.20 & 3.05 \\
\hline 7 & & 2.0 & 115.6 & 1.25 & 9.76 & 24.39 & 6.10 \\
\hline 8 & & 4.0 & 231.2 & 2.50 & 19.51 & 48.78 & 12.20 \\
\hline 9 & Control & 0.0 & 0.00 & 0.00 & 0.00 & 0.00 & 0.00 \\
\hline
\end{tabular}

* Total dose in crop cycle. ${ }^{* *}$ Individual dose in each of four applications. ${ }^{* *}$ Volume of water $400 \mathrm{~L} \mathrm{ha}{ }^{-1}$ in each of four applications.

\section{Variables evaluated}

Growth variables. At 90 DAP, a destructive analysis of the aerial parts of the plants was performed. The fresh weight of the leaves and stems of each plant was determined, and the leaf area (LA) $\left(\mathrm{cm}^{2}\right)$ was quantified with a Li-3100 (LI- COR Inc., USA). The dry weight of the organs was determined after drying in an oven at $70{ }^{\circ} \mathrm{C}$ for $72 \mathrm{~h}$. With the dry weight of the aerial part (DW) and LA, the growth physiological index specific leaf area (SLA) was determined (Gardner et al., 2003).

Electrolyte leakage (EC). For the measurements, 0.5-1 $\mathrm{cm}^{3}$ leaf segments were taken from the middle-third of the plants to determine the loss of electrolytes in the leaves (ECh). To measure the loss of electrolytes in the stem (ECt), $1 \mathrm{~cm}$ long parts of the main stems were taken. The method of Mohammed et al. (2002) and Barrett and Douglass (2004) was employed to measure the electrical conductivity of the solutions at $30^{\circ} \mathrm{C}\left(\mathrm{EC} 30^{\circ} \mathrm{C}\right)$ and $100^{\circ} \mathrm{C}\left(\mathrm{EC} 100{ }^{\circ} \mathrm{C}\right)$. The percentage of electrolyte leakage from the cells was determined with (1):

$$
\mathrm{EC}(\%)=\left(\mathrm{EC} 30^{\circ} \mathrm{C} / \mathrm{EC} 100{ }^{\circ} \mathrm{C}\right) \times 100 \%
$$

Proline contents. Fresh plant material of the leaves from the middle-third of the plants was used. Absorbance at $\lambda=520 \mathrm{~nm}$ was measured with a spectrophotometer (Spectronic ${ }^{\circledR}$ 501, Milton Roy, Rochester, NY) using toluene as the blank (adapted from Bates et al. (1973)). The proline concentration was determined on a fresh weight (FW) basis with (2):
Proline contents $(\mu \mathrm{M}) / \mathrm{g}$ FW $=$

( $(\mu \mathrm{g}$ proline $/ \mathrm{mL}) \times \mathrm{mL}$ toluene $) /(115.5 \mu \mathrm{g} / \mu \mathrm{M})$

\section{RESULTS AND DISCUSSION}

\section{Growth variables}

The dry mass of the aerial part had the highest response for the dose of $1.0 \mathrm{~kg} \mathrm{ha}^{-1} \mathrm{~B}$ as Na borate with a $15.85 \%$ relative increase in DW (Fig. 1 ), and, for boric acid, a $25.1 \%$ relative increase in DW was obtained with respect to non-foliar application of $B$, which is consistent with that reported by Asad et al. (2002). Significant differences $(P<0.01)$ were found between the B sources for DW, LA, and SLA (Figs. 1-3), with a lesser toxic effect of $B$ on DW for boric acid, as compared to $\mathrm{Na}$ borate at doses higher than $2 \mathrm{~kg} \mathrm{ha}^{-1}$ (Fig. 1); these concentrations of $\mathrm{B}$ as $\mathrm{Na}$ borate reduced the DW by around $25 \%$ with respect to the non-application of B (Fig. 1). This phenomenon can be explained by the interaction between $\mathrm{B}$ and $\mathrm{Na}$, which potentiates salinity stress and slows down transpiration and growth processes in a more restrictive way, reaffirming the findings of Bonilla and González (2011) and Dominic and Jithin (2012).

The lower impact of B stress on the DW at doses higher than $2 \mathrm{~kg} \mathrm{ha}^{-1}$ of boric acid could be explained by the lower accumulation of $B$ in tissues, the relative increase in $\mathrm{B}$ mobility, and the absence of $\mathrm{Na}$ in the source since boric acid penetrates the double layer of membrane phospholipids through simple diffusion 
and is transported by B-polyol complexes that allow bidirectional movement of $\mathrm{B}$, with distribution in organs with a low concentration of $\mathrm{B}$, as observed by Reid (2010). This lower impact of boric acid toxicity on DW was also reported by Karabal et al. (2003) in barley, but contradicts the results of Reid (2010), who suggested that $B$ toxicity is not completely explained by an osmotic stress of $\mathrm{B}$, but also by an interaction with other synergistic abiotic factors, such as photooxidation and other synergistic ions.

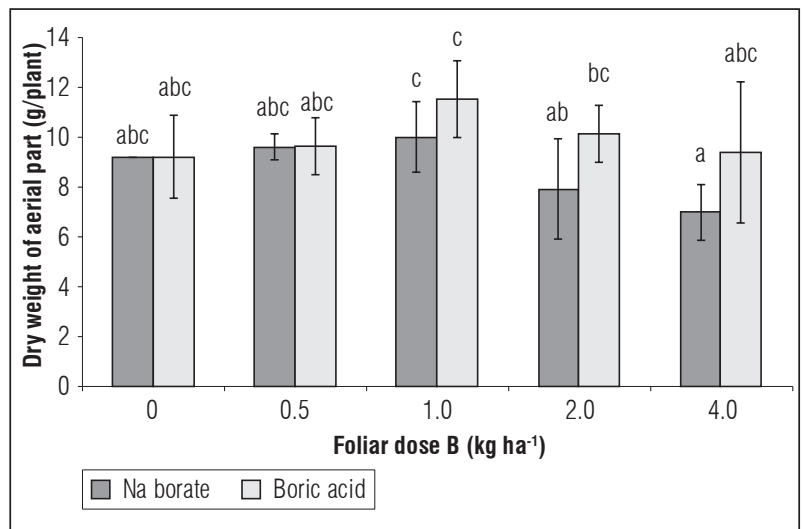

Figure 1. Effect of foliar application of different doses and sources of $B$ on dry mass of aerial parts (DW) of yellow diploid potato cv. Criolla Galeras. Means with different letters indicate a significant difference according to Tukey's test $(P \leq 0.05)$. The bars correspond to standard deviation.

The highest DW was seen with the B dose $1 \mathrm{~kg} \mathrm{ha}^{-1}$ cycle $^{-1}$ for both sources of $\mathrm{B}$, which evidenced the positive effect of foliar fertilization with $\mathrm{B}$ on the cultivation of yellow diploid potato cv. Criolla Galeras and confirmed the results of García and Poveda (2014), who obtained positive responses in DW when applying $0.5-1.0 \mathrm{~kg} \mathrm{ha} \mathrm{p}^{-1}$ of foliar $\mathrm{B}$ as boric acid in $\mathrm{cv}$. Criolla Colombia. The responses to doses of foliar $\mathrm{B}$ in Group Phureja were lower than those caused by edaphic B applications, where an increase in DW has been found with doses of $1.5 \mathrm{~kg} \mathrm{ha}^{-1}$ in cvs. Yema de Huevo and Criolla Colombia (Pérez et al., 2008). These positive responses in growth coincided with the beneficial effects of $B$ on productivity in several crops (Fernández et al., 2013; Archana and Verma, 2017), indicating the positive physiological functions of $B$ in the elongation of new aerial organs, activating metabolic processes, such as the synthesis of nucleic acids, proteins, amino acids, starch, auxins, and phenolics, and transport of assimilates; however, B toxicity inhibits these functions (Cervilla et al., 2012; Shah et al., 2017).

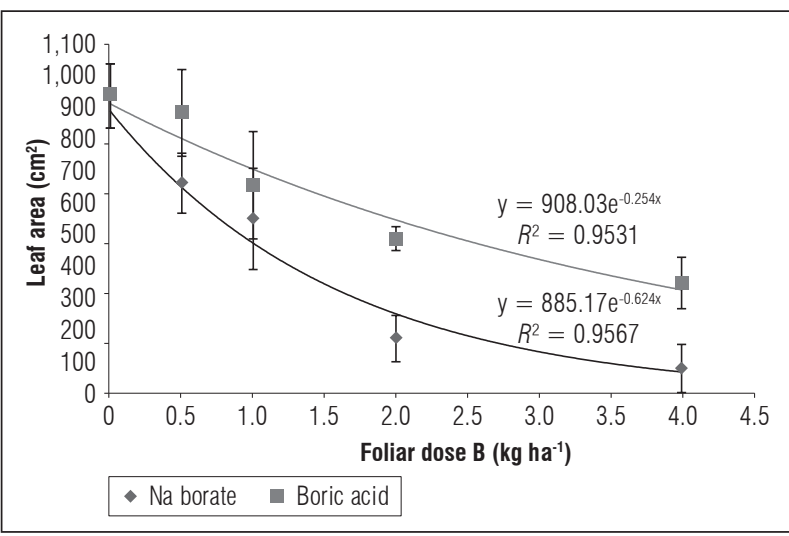

Figure 2. Effect of foliar application of different doses and sources of $B$ on the leaf area (LA) of yellow diploid potato cv. Criolla Galeras. The bars correspond to standard deviation.

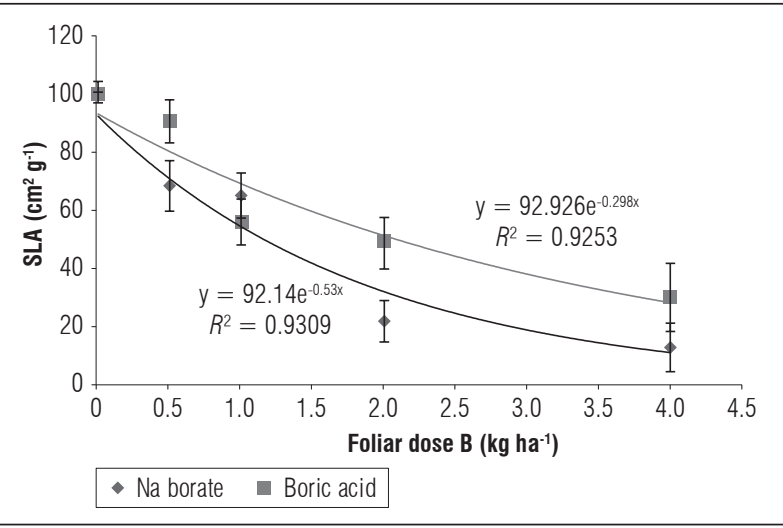

Figure 3. Effect of foliar application of different doses and sources of $B$ on the specific leaf area (SLA) of yellow diploid potato cv. Criolla Galeras. The bars correspond to standard deviation.

The highest responses in LA and SLA of the plants were observed with doses between $0-0.5 \mathrm{~kg} \mathrm{ha}^{-1}$ foliar $\mathrm{B}$ (Figs. 2 and 3 ); these $\mathrm{B}$ concentrations did not differ significantly $(P<0.05)$ for the source of boric acid, but differed for the source of $\mathrm{Na}$ borate. In addition, significant differences were found for the doses higher than $2 \mathrm{~kg} \mathrm{ha}^{-1} \mathrm{~B}$ between the sources, with a reduction in LA and SLA greater than 50\%; whereas, with a dose of $4 \mathrm{~kg} \mathrm{ha}^{-1} \mathrm{~B}$, these reductions were about $65 \%$ for boric acid and about $90 \%$ for $\mathrm{Na}$ borate. This phenomenon can be explained by the reduction in leaf expansion in mature and new leaves, where toxic doses of $\mathrm{B}$ alter the structure of primary metabolites ATP, $\mathrm{NADH}, \mathrm{NADPH}$ and the formation of bonds with RNA ribose, which limits RNA synthesis, affecting the formation of leaves and other organs, as reported 
by Reid et al. (2010) and Bonilla and González (2011). On the other hand, the decrease of LA at toxic doses of B ( 2 and $4 \mathrm{~kg} \mathrm{ha}^{-1}$ ) in the cv. Criolla Galeras could be explained by abscission and death of old leaves, as observed in the field, where high concentrations of $\mathrm{B}$ might act as an inducer of abscisic acid synthesis (Bonilla and González, 2011; Macho et al., 2017). The restriction on growth by toxic levels of $\mathrm{B}$ was also observed in rice by Dominic and Jithin (2012), in citrus by Keles et al. (2004) and in tomatoes by Cervilla (2009); the latter report indicated decreases in LA and DW at toxic levels of $2 \mathrm{mM}$ of edaphic $\mathrm{B}$ applications. In general, a lower LA before tuber filling affects the accumulation of DW and yield in S. tuberosum (Herrera and Rodríguez, 2011).

The toxic effect of $\mathrm{B}$ on growth could also be attributed to the fact that excess $\mathrm{B}$ reduces $\mathrm{NO}_{3}{ }^{-}$conversion to $\mathrm{NH}_{4}{ }^{+}$and, therefore, inhibits $\mathrm{N}$ metabolism and efficient formation of proteins as proposed Seth and Aery (2017). Additionally, high amounts of B in various crops decrease the growth of vegetative organs, chlorophyll contents, and photosynthetic rates as the result of osmotic imbalances and the inability to resist oxidative damage increases from photooxidation (Herrera et al., 2010).

The application of boric acid favored the growth rates for yellow diploid potato cv. Galeras, which resulted in the highest accumulation of DW and was related to a higher LA and SLA, with respect to the control and $\mathrm{Na}$ borate. Even when applied at high doses, boric acid (2 and $4 \mathrm{~kg} \mathrm{ha}^{-1}$ ) showed significant differences $(P<0.05)$ with respect to the highest toxicity exerted by $\mathrm{Na}$ borate (Figs. 2 and 3); apparently, this was because of the effects of $\mathrm{Na}$ ions and possible osmotic stress in the plants (Reid et al., 2004; Dominic and Jithin, 2012).

Plants that accumulate high levels of $B$ can have mechanisms of B exclusion with guttation or accumulation in organs, such as the stem, and can present adequate growth in DW (Cervilla et al., 2012). These mechanisms might explain the highest effect of osmotic stress on the margins of the yellow diploid potato leaves of cv. Criolla Galeras because of accumulation of $\mathrm{Na}$ when used as an accompanying cation in sources of foliar B applications, with respect to boric acid, as was evidenced by the symptoms in field (Fig. 4). These results indicate a higher tolerance of the plants to B applied as boric acid and corroborate the positive responses of foliar boric acid applications, as described by Brown and $\mathrm{Hu}$ (1998) and
Fernández et al. (2013). The results of the current study establish that yellow diploid potato cv. Criolla Galeras is tolerant to foliar applications of boric acid at doses of 0.5 to $2 \mathrm{~kg} \mathrm{ha}^{-1}$ although it is important to evaluate the effect of $\mathrm{B}$ applications on tuberization and commercial production in future studies.
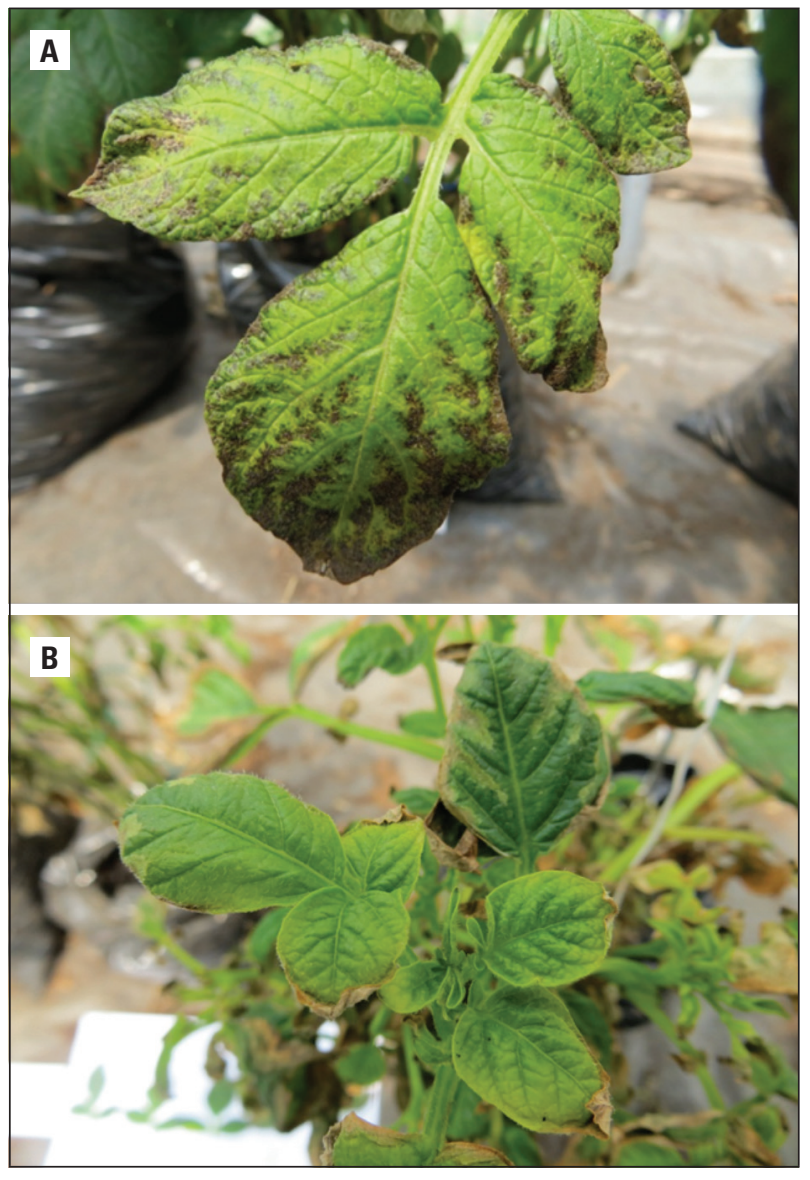

Figure 4. Symptoms of B toxicity in yellow diploid potato cv. Criolla Galeras. The marginal and intervenal necrosis accompanied by chlorosis are evidenced in the leaf lamina of mature leaves $(A)$ and the reduction in growth, with deformation and necrosis (B) of new leaves.

\section{Metabolic responses}

Highly significant differences $(P<0.001)$ were observed in the ECh, with a linear response of this variable and a high coefficient of determination $\left(R^{2}>\right.$ 0.96 ) with the increasing doses of $B$ for both sources in cv. Criolla Galeras (Fig. 5). This coincides with the reports by Karabal et al. (2003) for barley and by Siddiqui et al. (2013) for the radish, who found higher percentages of ECh in leaves treated with $\mathrm{B}$ 
as the dose of $B$ increased (5-10 mM) although at different proportions than in the results obtained for cv. Criolla Galeras in the current study and with differences obtained between the species. Different types of abiotic stress can have similar effects on plants, which could be related to alterations in the integrity of the cell membranes (Reid, 2010; Savic et al., 2012). B toxicity promotes the appearance of reactive oxygen species, which affect metabolic processes through the alteration of lipids and can cause cell death, promoting a greater exchange of cytosol ions with the outside of the cell (Reid et al., 2004; Cervilla et al., 2012); therefore, the measurement of free electrolytes becomes an indicator of the loss of membrane stability caused by osmotic stress (Karabal et al., 2003; Cha-Um et al., 2010).

Savic et al. (2012), under conditions of heat stress in S. tuberosum, reported an ECh of $30 \%$ in tolerant potato cultivars, such as Laura, and an ECh of $75 \%$ in sensitive cultivars, such as Desiree. For nutritional stress resulting from excess $B$, with the maximum dose of $4 \mathrm{~kg} \mathrm{ha}^{-1}$, the $\mathrm{cv}$. Criolla Galeras in the present study reached as ECh of $62 \%$ for $\mathrm{Na}$ borate, which presented significant differences $(P<0.001)$ from the maximum dose of boric acid that resulted in higher stability in the membranes, with an ECh of $28 \%$. This stress indicator corroborated a greater oxidative damage in membranes for $\mathrm{Na}$ borate, where a higher slope of the trend line was observed with respect to that of boric acid (Fig. 5). In addition, a greater $\mathrm{EC}$ was observed with the foliar doses of $\mathrm{B}$, exceeding $2 \mathrm{~kg} \mathrm{ha}^{-1}$ (Fig. 5), which coincides with the reduced values of the growth variables

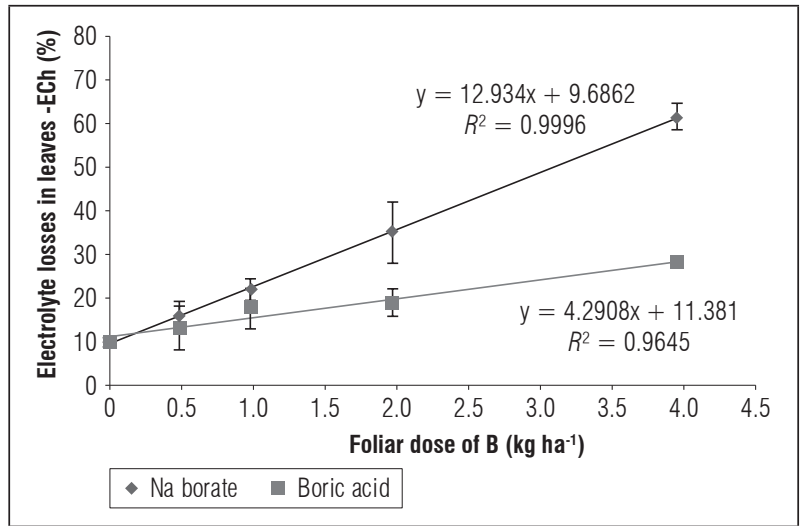

Figure 5. Effect of foliar application of different doses and sources of B on electrolyte loss (\%) in leaves (ECh) of yellow diploid potato cv. Criolla Galeras. The bars correspond to standard deviation.
(DW, LA, SLA) and the greater increases in proline contents (Fig. 6), which behaves as a compatible osmolyte and avoids oxidative stress resulting from excess $\mathrm{B}$, protecting membranes and proteins in the cells (Dominic and Jithin, 2012).

Excess B limits the accumulation of solutes in plants; in young leaves, cell turgor can be reduced, accompanied by leaf chlorosis and deformations; while, in mature leaves, the accumulation of B favors osmotic stress, with membrane instability and high ion mobility that affect new tissues (Reid et al., 2004; Dominic and Jithin, 2012). In comparison with the non-application of $\mathrm{B}$, the $\mathrm{B}$ dose of $4 \mathrm{~kg} \mathrm{ha}^{-1}$ resulted in a loss of six times more electrolytes for $\mathrm{Na}$ borate and three times more electrolytes for boric acid (Fig. $5)$. This proves that the B stress did not only depend on the dose, but also on the source; in this case, the interaction with the accompanying $\mathrm{Na}$ ion favored greater stress, confirming the report by Dominic and Jithin (2012).

For the doses 0.5 and $1.0 \mathrm{~kg} \mathrm{ha}^{-1}$ per cycle of foliar B, no significant differences for the ECh were observed, with ECh losses of 10 and 20\%, respectively (Fig. 5), signifying that, for these doses, the integrity of the membranes was maintained at tolerable and manageable levels for cv. Criolla Galeras, which corresponded to the highest accumulation of DW (Fig. 1) and contrasted with insignificant losses of stem-free electrolytes (ECt) (data not shown). The ECh turned out to be a more reliable measurement in the evaluation of the EC; while for ECt, in future research, relating concentrations of the free ions $\mathrm{B}, \mathrm{K}$ and $\mathrm{Na}$ in the leaf

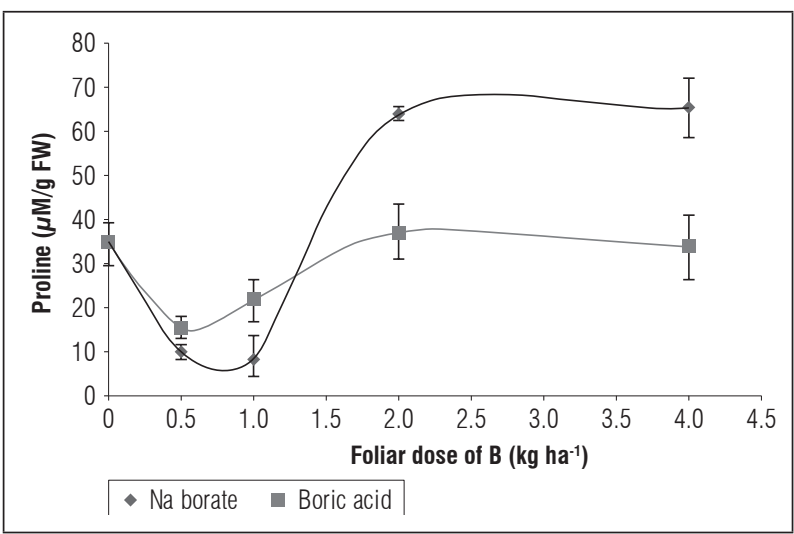

Figure 6. Effect of foliar application of different doses and sources of $B$ on proline contents $(\mu \mathrm{M} / \mathrm{g}$ fresh weight) in yellow diploid potato cv. Criolla Galeras leaves. The bars correspond to standard deviation. 
and stem sap is recommended in order to establish a better comparison.

After the application of different concentrations of $\mathrm{B}$ in yellow diploid potato cv. Criolla Galeras, treatments with both sources increased the proline concentrations, with significant differences with respect to the control and differences between the sources. Less proline was accumulated after the foliar treatments with boric acid (Fig. 6), a source that did not cause significant differences $(P<0.05)$ in the proline dynamics because of $\mathrm{B}$ toxicity in barley according to Karabal et al. (2003), while Na could increase proline levels in rice via the Ornithine route instead of the Glutamate route (Dominic and Jithin, 2012). On the other hand, Siddiqui et al. (2013) found that the radish increased proline levels when B toxicity was mitigated by Ca. Levy, and Veilleux (2007) and Cervilla et al. (2012) revealed an increase of this amino acid in potato and tomato plants subjected to B toxicity.

Proline could be accumulated in cells as a result of an increase in its biosynthesis or alteration in the synthesis/degradation of proteins (Cervilla et al., 2012, Dominic and Jithin, 2012). This leads to the conclusion that, for the doses 0.5 and $1.0 \mathrm{~kg} \mathrm{ha}^{-1}$ of foliar $\mathrm{B}$, the cv. Criolla Galeras plants presented lower concentrations of proline than the control treatment, probably because of a reduced biosynthesis of proline since these were the treatments with lower stress (Fig. 6), which indicated better metabolic conditions related to a higher accumulation of DW and lower permeability of membranes, as discussed above. The doses greater than $1.0 \mathrm{~kg} \mathrm{ha}^{-1}$ of foliar B significantly increased the concentrations of proline in the leaves (Fig. 6), implying an increase in membrane degradation and proteins, which were related to the highest ECh, which reached the highest levels at doses of 2 and $4 \mathrm{~kg} \mathrm{ha}^{-1} \mathrm{~B}$. Cervilla (2009) found that, in mature tomato leaves, an increase in proline as a result of excess B was inversely proportional to biomass accumulation and was the result of the inadequate metabolism of $\mathrm{NO}_{3}{ }^{-}$reduction (Cervilla et al., 2012). These data suggest that, regardless of its protective role, an increase in proline concentration is another indicator of the stress produced by $\mathrm{B}$ toxicity in potato cv. Criolla Galeras.

The evaluated variables responded better to the treatments with boric acid than to the ones with $\mathrm{Na}$ borate. This might have been due to this source having better mobility in short- and long-distance transport, avoiding accumulation in the leaves, and being distributed to sources with the formation of complex esters or lignified structures in cell walls, corroborating the proposal by Herrera et al. (2010), in such a way that, under conditions with high concentrations of $\mathrm{B}$, this type of bond is stronger than free $\mathrm{B}$, which can be a detoxification mechanism for this mineral nutrient in some species.

\section{CONCLUSIONS}

In the potatoes, a possible osmotic stress, as indicated by the increased proline contents, was generated with $\mathrm{B}$ doses higher than $1.0 \mathrm{~kg} \mathrm{ha}^{-1}$, causing oxidative stress with irreversible damage related to decreases in the growth variables DW, LA, and SLA and a significant increase in ECh. ECh and proline contents in leaves could be used as stress indicators as a result of $\mathrm{B}$ in the yellow diploid potato cv. Criolla Galeras.

The lower impact of B stress exerted by the boric acid as compared to $\mathrm{Na}$ borate on the evaluated variables suggests that formulations or foliar applied products of $B$ in potatoes should be based on boric acid. The symptoms of B toxicity were characterized for the yellow diploid potato cv. Criolla Galeras, presenting severe marginal and intervenal necrosis associated with chlorosis in leaves and, for new leaves, the reduction of growth, deformation of leaves, and marginal necrosis and generalized chlorosis. The results of this research could be used to search for good fertilization management practices with $\mathrm{B}$ in yellow diploid potatoes under the conditions of the Cundiboyacense highlands.

\section{ACKNOWLEDGMENTS}

The authors express their gratitude to the Faculty of Agricultural Sciences of the Universidad Nacional de Colombia, Bogota.

Conflict of interests: this manuscript was prepared and reviewed with the participation of all authors, who declare that there exists no conflict of interest that puts at risk the validity of the presented results.

\section{BIBLIOGRAPHIC REFERENCES}

Agronet. 2016. Área, producción y rendimiento por cultivo: papa criolla. In: http://www.agronet.gov.co/estadistica/Paginas/default.aspx; consulted: April, 2018. 
Archana, P.N. and P. Verma. 2017. Boron deficiency and toxicity and their tolerance in plants: a review. J. Global Biosci. 6, 4958-4965.

Asad, A., F.P. Blamey, and D. Edwards. 2002. Dry matter production and boron concentrations of vegetative and reproductive tissues of canola and sunflower plants grown in nutrient solution. Plant Soil 243(1), 243-252. Doi: 10.1023/A:1019909130031

Ayvaz, M., M.K. Avci, C. Yamaner, M. Koyuncu, A. Guven, and K. Fagerstedt. 2013. Does excess boron affect the malondialdehyde levels of potato cultivars? Eur. Asian J. BioSci. 7, 47-53. Doi: 10.5053/ejobios.2013.7.0.6

Barrett, W. and J. Douglass. 2004. Electrolyte leakage from stem tissue as an indicator of hardwood seedling physiological status and hardiness. USDA Forest Service. In: http://www.fs.fed.us; consulted: June 15, 2018.

Bates, L.S., R.P. Waldren, and I.D. Teare. 1973. Rapid determination of free proline for water-stress studies. Plant Soil 39, 205-207. Doi: 10.1007/BF00018060

Bonilla, G. and A. González. 2011. Salt stress in vascular plants and its interaction with boron toxicity. pp. 2227-240. In: Vasanthaiah, H. (ed). Plants and environment. In Tech, Rijeka, Croatia. Doi: 10.5772/24892

Brown, P.H. and H. Hu. 1998. Phloem boron mobility in diverse plant species. Bot. Acta 111, 331-335. Doi: 10.1111/j.1438-8677.1998.tb00717.x

Castro, H. and M.I. Gómez. 2010. Fertilidad de suelos y fertilizantes aplicados al trópico colombiano. Universidad Pedagógica y Tecnológica de Colombia, Tunja, Colombia.

Cervilla, L. 2009. Respuesta fisiológica y metabólica a la toxicidad por boro en plantas de tomate. Estrategias de tolerancia. PhD thesis. Universidad de Granada, Granada, Spain.

Cervilla, L., B. Blasco, J. Ríos, M. Rosales, E. Sánchez, M. Rubio, L. Romero, and J. Ruiz. 2012. Parameters symptomatic for boron toxicity in leaves of tomato plants. J. Bot. 2012, 726206. Doi: 10.1155/2012/726206

Cha-Um, S., T. Takabe, and C. Kirdmaneei. 2010. Ion contents, relative electrolyte leakage, proline accumulation, photosynthetic abilities and growth characters of oil palm seedlings in response to salt stress. Pak. J. Bot. 42(3), 2191-2020.

Di Gioia, F., A. Aprile, E. Sabella, P. Santamaria, A. Pardossi, A. Miceli, L. De Bellis, and E. Nutricati. 2017. Grafting response to excess boron and expression analysis of genes coding boron transporters in tomato. Plant Biol. 19, 728-735. Doi: 10.1111/plb.12589

Dominic, V. and T. Jithin. 2012. Effect of $\mathrm{NaCl}$ and boron toxicity on proline biosynthesis of Oryza sativa Int. J. Life Sci. Pharm. 1(3), 74-83.

Eichert, T. and H.E. Goldbach. 2010. Transpiration rate affects the mobility of foliar-applied boron in Ricinus communis L. cv. Impala. Plant Soil 328, 165-174. Doi: 10.1007/s11104-009-0094-y

Fernández, V., T. Sotiropoulos, and P. Brown. 2013. Foliar fertilization: scientific principles and field practices. IFA, Paris.

García, G. and G. Poveda. 2014. Efecto de la aplicación foliar de $\mathrm{K}, \mathrm{B}$ y $\mathrm{Zn}$ sobre el rendimiento y calidad del tubérculo en papa criolla (Solanum tuberosum, Grupo Phureja) cultivar Criolla Colombia. Undergraduate thesis. Faculty of Agricultural Sciences, Universidad Nacional de Colombia, Bogotá.

Gardner, F.P., R.B. Pearce, and R. Mitchell. 2003. Physiology of crop plants. Blackwell Publishing Company, Ames, IA.

Herrera, M., A. González, J. Rexach, J. Camacho, J. Maldonado, and M. Navarro. 2010. Role of boron in vascular plants and response mechanisms to boron stresses. Plant Stress 4(1), 115-122.

Herrera, A. and L.E. Rodríguez. 2011. Tecnologías de producción y transformación de papa criolla. Universidad Nacional de Colombia, Bogota.

Karabal, E., M. Yücel, and A. Öktem. 2003. Antioxidant responses of tolerant and sensitive barley cultivars to boron toxicity. Plant Sci. 164(1), 925-933. Doi: 10.1016/ S0168-9452(03)00067-0

Keles, Y., I. Öncel, and N. Yenice. 2004. Relationship between boron content and antioxidant compounds in Citrus leaves taken from fields with different water source. Plant Soil 265, 345-353. Doi: 10.1007/ s11104-005-0646-8

Levy, D. and R. Veilleux. 2007. Adaptation of potato to high temperatures and salinity a review. Am. J. Potato Res. 84, 487-506. Doi: 10.1007/BF02987885

Macho, M.Á., J.J. Camacho, M.B. Herrera, M. Müller, S. Munné, and A. González. 2017. Abscisic acid and transpiration rate are involved in the response to boron toxicity in Arabidopsis plants. Physiol. Plant. 160(1), 21-32. Doi: 10.1111/ppl.12534

Metwally, A., R. El-Shazoly, and M. Hamada. 2012. Effect of boron on growth criteria of some wheat cultivars. J. Biol. Earth Sci. 2(1), 1-9.

Mohammed, B., K. Jean, and L. Stanley. 2002. The use of the electrolyte leakage method for assessing cell membrane stability as a water stress tolerance test in durum wheat. Plant Growth Regul. 36(1), 61-70. Doi: 10.1023/A:1014732714549

Pérez, L., L. Rodríguez, and M. Gómez. 2008. Efecto del fraccionamiento de la fertilización con $\mathrm{N}, \mathrm{P}, \mathrm{K}$ y Mg y la apllicación de los micronutrientes B, Mn y Zn en el rendimiento y calidad de papa criolla (Solanum Phureja) variedad Criolla Colombia. Agron. Colomb. 26(3), 477-486

Reid, R., J. Hayes, A. Post, J. Stangoulis, and R. Graham. 2004. A critical analysis of the causes of boron toxicity 
in plants. Plant Cell Environ. 27(11), 1405-1414. Doi: 10.1111/j.1365-3040.2004.01243.x

Reid, R. 2010. Can we really increase yields by making crop plants tolerant to boron toxicity? Plant Sci. 178(1), 9-11. Doi: 10.1016/j.plantsci.2009.10.006

Rodríguez, L., C. Nustez, and N. Estrada. 2009. Criolla Latina, Criolla Paisa y Criolla Colombia, nuevos cultivares de papa criolla para el departamento de Antioquia (Colombia). Agron. Colomb. 27(3), 289-303.

Ruiz, J., M. Rivero, and L. Romero. 2003. Preliminary studies on the involvement of biosynthesis of cysteine and glutathione concentration in the resistance to $B$ toxicity in sunflower plants. Plant Sci. 165, 811-817. Doi: 10.1016/S0168-9452(03)00276-0

Savic, J., I. Dragicevic, and D. Pantelic. 2012. Expression of small heat shock proteins and heat tolerance in potato
(Solanum tuberosum L.). Arch. Biol. Sci. 64(1), 135-144. Doi: 10.2298/ABS1201135S

Seth, K. and N.C. Aery. 2017. Boron induced changes in biochemical constituents, enzymatic activities, and growth performance of wheat. Acta Physiol. Plant. 39(11), 244. Doi: 10.1007/s11738-017-2541-3

Shah, A., X. Wu, A. Ullah, S. Fahad, R. Muhammad, L. Yan, and C. Jiang. 2017. Deficiency and toxicity of boron: Alterations in growth, oxidative damage and uptake by citrange orange plants. Ecotoxic. Environm. Safety 145, 575-582. Doi: 10.1016/j.ecoenv.2017.08.003

Siddiqui, M., M. Sakran, M. Hayssam, O. Mohammed, M. Faisal, and A. Alatar. 2013. Calcium-induced amelioration of boron toxicity in radish. J. Plant Growth Regul. 32, 61-71. Doi: 10.1007/s00344-012-9276-6 